Research Paper

\title{
Stem Cell Transplantation Increases Antioxidant Eifects in Diabetic Mice
}

\author{
Ming Li ${ }^{1}$, Luca Vanella ${ }^{2}$, Yuming Zhang ${ }^{3}$, Ming Shi ${ }^{1}$, Takashi Takaki, Joseph I Shapiro², \\ Susumu Ikehara ${ }^{1 凶}$ \\ 1. Department of Stem Cell Disorders, Kansai Medical University, Moriguchi City, Osaka, Japan. \\ 2. School of Medicine, University of Marshall, 1600 Medical Center Drive, Huntington, WV 25701, USA. \\ 3. Department of Pediatrics, Nanfang Hospital, Guangzhou, China. \\ 4. JEOL Ltd., Tokyo, Japan.
}

$\triangle$ Corresponding author: Susumu Ikehara, M.D., Ph.D., Department of Stem Cell Disorders, Kansai Medical University, Moriguchi City, Osaka 570-8506, Japan. Telephone: 81-6-6993-9625; Fax: 81-6-6994-9627; e-mail: ikehara@takii.kmu.ac.jp.

() Ivyspring International Publisher. This is an open-access article distributed under the terms of the Creative Commons License (http://creativecommons.org/ licenses/by-nc-nd/3.0/). Reproduction is permitted for personal, noncommercial use, provided that the article is in whole, unmodified, and properly cited.

Received: 2012.05.26; Accepted: 2012.09.13; Published: 2012.10.27

\begin{abstract}
Intra bone marrow-bone marrow transplantation (IBM- BMT) + thymus transplantation (TT) has been shown to reduce the incidence of graft versus host disease (GVHD) and restore donor-derived $T$ cell function. In addition, an increase in insulin sensitivity occurred in $\mathrm{db} / \mathrm{db}$ mice after IBM-BMT+TT treatment. Heme oxygenase (HO)-I is a stress inducible enzyme which exert antioxidant, antiapoptotic, and immune-modulating properties. We examined whether IBM-BMT+TT could modulate the expression of HO-I in the kidneys of $\mathrm{db} / \mathrm{db}$ mice. Six-week-old db/db mice with blood glucose levels higher than $250 \mathrm{mg} / \mathrm{dl}$ were treated with IBM-BMT+TT. Six weeks later, the db/db mice showed decreased body weight, blood glucose levels and insulin, and increased plasma adiponectin levels. The upregulation of $\mathrm{HO}-\mathrm{I}$ was associated with significantly $(p<0.05)$ increased levels of peNOS and PAKT, but decreased levels of iNOS in the kidneys of $d b / d b$ mice. Plasma creatinine levels also decreased $(p<0.05)$, and the expression of type IV collagen was improved. Thus IBM-BMT+TT unregulated the expression of HO-I, peNOS and pAKT, while decreasing iNOS levels in the kidney of $d b / d b$ mice. This was associated with an improvement in renal function.
\end{abstract}

Key words: IBM-BMT+TT, antioxidant, HO-1, diabetic nephropathy.

\section{Introduction}

Heme oxygenase (HO)- 1 is a stress inducible enzyme that catalyzes the degradation of heme proteins into free iron, $\mathrm{CO}$ and biliverdin, which is then rapidly converted into bilirubin. These catabolic end products exert antioxidant, antiapoptotic, and immune-modulating properties, rendering the overall function of HO-1 to be cytoprotective [1, 2]. Graft versus host disease (GVHD) is a major side effect of allogenic bone marrow transplantation (BMT) [3]. Intra bone marrow- BMT (IBM-BMT) appears to offer the best approach for allogenic BMT, as manifested by a reduced incidence of GVHD and the restoration of donor-derived $\mathrm{T}$ cell function [4-6]. We recently re- ported that, in $\mathrm{db} / \mathrm{db}$ mice treated with IBM-BMT+ thymus (TT) transplantation, CD4/CD8 ratios were normalized with a consequent increase in plasma adiponectin levels and insulin sensitivity. In addition, the expression of pancreatic phosphorylated AK transforming factor (pAKT), phosphorylated liver kinase B1 (pLKB1), phosphorylated adenosine monophosphate-activated protein kinase (pAMPK) and $\mathrm{HO}-1$ increased in thus-treated $\mathrm{db} / \mathrm{db}$ mice [7].

The $\mathrm{db} / \mathrm{db}$ mouse presents with renal abnormalities including proteinuria, glomerular hypertrophy, and glomerulosclerosis $[8,9]$, thereby making it an ideal animal model in which to study renal and 
vascular dysfunction in diabetic nephropathy (DN). $\mathrm{DN}$ is the major cause of end-stage renal failure, mainly due to the increased incidence of type 2 diabetes mellitus [10]. Oxidative stress (OS) is considered a significant pathogenic factor in the development of diabetic vascular complications, including nephropathy $[11,12]$. The beneficial effect of increased HO-1 expression and $\mathrm{HO}$ activity further suggests that the abnormality in endothelial progenitor cells is due to a mesenchymal stem cell (MSC) disorder exacerbated by OS and decreased levels of adiponectin [13].

In the present study, we examined whether allogenic IBM-BMT+TT modulated the expression of HO- 1 in the kidneys of $\mathrm{db} / \mathrm{db}$ mice and show that this intervention does indeed upregulate the expression of HO-1, phosphorylated endothelial nitric oxide synthase (peNOS) and pAKT, decrease inducible NOS (iNOS), and improve renal function, therefore providing a mechanistic basis for the therapeutic use of IBM-BMT+TT.

\section{Materials and methods}

\section{Animals}

Six-, 12- and 30-wk-old BKS.Cg-m+Lepr ${ }^{\mathrm{db}}$ / + Lepr $^{\mathrm{db}} / \mathrm{J}\left(\mathrm{H}-2 \mathrm{~K}^{\mathrm{d}}\right)(\mathrm{db} / \mathrm{db})$ mice and age-matched lean mice were purchased from Charles River Laboratories (Yokohama, Japan) and maintained in animal facilities under specific pathogen-free conditions. All procedures were performed under protocols approved by the Institutional Animal Care and Use Committee at Kansai Medical University. Body weight and blood glucose levels were measured each week. Blood glucose levels higher than $250 \mathrm{mg} / \mathrm{dl}$ on two consecutive measurements were considered to indicate the onset of diabetes. Each experiment was repeated three times.

\section{IBM-BMT+TT}

Six-wk-old $\mathrm{db} / \mathrm{db}$ mice with blood glucose levels greater than $250 \mathrm{mg} / \mathrm{dl}$ and proteinuria greater than ++ on two consecutive measurements received fractionated irradiation twice a day $(5.0 \mathrm{~Gy} \times 2$, 4-hour interval). One day after irradiation, whole BMCs from B6 mice were injected into the recipient mice $\left(1 \times 10^{7} /\right.$ mouse $)$ by IBM-BMT using our previously-described method [7]. Simultaneously, the thymus from newborn B6 mice was grafted under the renal capsule of the left kidney of the recipient mice. All treated mice were sacrificed $6 \mathrm{wks}$ after IBM-BMT+TT treatment.

\section{Immunochemistry and measurement of nitric oxide (NO) levels}

The pancreata, livers, kidneys and bones of lean and $\mathrm{db}$ mice were removed at each time point. After the tissues were fixed in $10 \%$ formalin for 24 hours at room temperature, they were embedded in paraffin. The sections (3- $\mu \mathrm{m}$ thick) were stained with hematoxylin and eosin. The pancreata were stained with polyclonal guinea pig anti-swine insulin antibody (N1542, Dako Cytomation, CA). The kidneys were stained with collagen type IV (Sigma-Aldrich, MO), pAKT, iNOS and eNOS (Abcam PLC, Cambridge, UK) antibodies. The stained sections were examined under a microscope.

NO levels in the kidneys were measured according to the manufacturer's protocol using a Nitric Oxide Assay Kit (BioAssay Systems, Hayward, CA).

\section{Electron microscopy}

The fixed renal cortices were embedded in epoxy resin using conventional methods [14]. Kidney tissue was fixed in $2.5 \%$ glutaraldehyde in 0.1M PBS, pH 7.4. Samples were washed and post fixed with $2 \%$ aqueous $\mathrm{OsO}_{4}$. The samples were then dehydrated with serially-increasing concentrations of ethanol (60 to $100 \%)$, and were infiltrated with epon mixed with methyl nadic anhydride (TAAB Laboratories, UK), Dodecenyl succinic anhydride (TAAB Laboratories), and Quetol-812 and DMP-30 (Nishin Company, Japan). Ultrathin sections were prepared, stained using uranyl acetate and lead citrate, and then examined with a JEM-1400A electron microscope (JEOL, Tokyo, Japan). The measurements were taken from electron micrographs with magnifications of $\times 2,500$ and $\mathrm{x} 12,000$.

Adiponectin, insulin, creatinine and pancreatic insulin content measurements

Adiponectin was determined in mouse plasma using an ELISA assay (R\&D Systems, Inc. MN and Invitrogen Corporation CA). Insulin was measured using an ELISA kit (Morinaga, Yokohama, Japan).

Plasma creatinine was measured according to the manufacturer's protocols using a plasma creatinine detection kit (Arbor Assays, Michigan).

For insulin content measurement, the pancreas was isolated and weighed, and then placed in $3 \mathrm{ml}$ cold acid ethanol $(0.18 \mathrm{M} \mathrm{HCl}$ in $70 \%$ ethanol) and homogenated. This was kept overnight at $4^{\circ} \mathrm{C}$ and centrifuged at $2400 \mathrm{rpm}$ for $30 \mathrm{~min}$ at $4^{\circ} \mathrm{C}$. The supernatant was transferred and stored at $-20^{\circ} \mathrm{C}$ for measurement using ELISA. 
Western blot analysis of kidney HO-I, peNOS, AKT, PAKT, and iNOS

At sacrifice, kidneys were dissected, then pooled for each mouse in order to measure signaling molecules. Specimens were stored at $-140^{\circ} \mathrm{C}$ until assayed. Frozen kidney tissues were pulverized under liquid nitrogen and placed in a homogenization buffer (mmol/1: 10 phosphate buffer, 250 sucrose, 1 EDTA, $0.1 \mathrm{PMSF}$ and $0.1 \% \mathrm{v} / \mathrm{v}$ tergitol, $\mathrm{pH} 7.5)$. Homogenates were centrifuged at $27,000 \mathrm{~g}$ for $10 \mathrm{~min}$ at $4^{\circ} \mathrm{C}$, and the supernatant was then isolated and protein levels were obtained by immunoblotting with the relevant antibodies. Antibodies against HO-1, AKT, phosphorylated AKT (pAKT), eNOS, peNOS and iNOS were obtained from Cell Signaling Technology, Inc. (Beverly, MA). Antibodies were prepared by dilution as described previously $[15,16]$.

\section{Flow cytometric analyses}

Peripheral blood mononuclear cells were obtained from the tail vein of mice 30 days after transplantation. These cells were stained with antibodies against PE-H-2Kd, PE-CD4, PE-CD8a and FITC-H-2K ${ }^{b}$ (BD Bioscience Pharmingen, San Diego, CA) for 30 min on ice. After washing twice with $2 \%$ FCS / PBS and lysing red blood cells, the 10000 events acquired were analyzed by FACScan (BD Bioscience). Isotype-matched immunoglobulins were used as controls.

\section{Statistical analysis}

Statistical significance between experimental groups was determined by the Fisher method of analysis of multiple comparisons. For comparison between treatment groups, the null hypothesis was tested by either a single-factor ANOVA for multiple groups or unpaired $t$ test for two groups. Statistical significance was regarded as significant at $\mathrm{p}<0.05$.

\section{Results}

\section{Body weight, thymus weight, and morphology of pancreas and bone, and insulin content of pancreas islet}

We first confirmed the parameters (body weight, thymus weight and morphology of pancreas and bone marrow) of the $\mathrm{db} / \mathrm{db}$ mice and lean mice (as control) maintained in our animal facilities (Fig.1), since food and environment may affect some parameters of $\mathrm{db} / \mathrm{db}$ mice. As seen in Fig. $1 \mathrm{~A}$, the body weight of 12-wk-old lean mice was significantly higher than that of 6-wk-old lean mice $(30.4 \pm 0.5$ vs $22.6 \pm 0.1 \mathrm{~g}$, $\mathrm{p}<$ 0.001 ). Similar results occurred in the $\mathrm{db} / \mathrm{db}$ mice (53.2 \pm 1.7 vs $33.5 \pm 0.03 \mathrm{~g}, \mathrm{p}<0.001)$. However, although the body weight of 30-wk-old db/db mice was significantly higher than that of 12 -wk-old $\mathrm{db} / \mathrm{db}$ mice $(61.2 \pm 0.6$ vs $53.2 \pm 1.7 \mathrm{~g}, \mathrm{p}<0.01)$, there was no significant difference in body weight between 30 -wk-old and 12 -wk-old lean mice $(32.4 \pm 0.5$ vs $30.4 \pm$ $0.5 \mathrm{~g}$ ). As shown in Fig. 1B, thymus weight was significantly lower in the 6-wk-, 12-wk and 30-wk-old $\mathrm{db} / \mathrm{db}$ mice than in the age-matched lean mice $(51.7$ \pm 4.7 vs $75.7 \pm 3.3,21.3 \pm 0.9$ vs $49 \pm 4.0,20.5 \pm 1.2$ vs $43 \pm 4.1 \mathrm{mg}, \mathrm{p}<0.05$ at each time point).

On HE staining, 12-wk- and 30-wk-old db/db mice (Fig. 1E and F) exhibited larger islets than 6 wk-old $\mathrm{db} / \mathrm{db}$ mice and lean mice (Fig. 1C and D). More adipocytes were present in the bone marrow of 12-wk- and 30-wk-old db/db mice (Fig. 1H-J) than in lean mice (Fig. 1G).

The $\mathrm{db} / \mathrm{db}$ mouse shows insulin resistance and insulin-positive cell failure. The insulin content (brown color) was much lower in the larger islets of 6-wk-, 12-wk- and 30-wk-old db/db mice (Fig. 1L-N) than in those of lean mice (Fig. 1K), suggesting that more insulin was secreted into the peripheral blood in the $\mathrm{db} / \mathrm{db}$ mice. Pancreatic insulin contents of lean mice $(2336 \pm 84.5 \mathrm{pg} / \mathrm{ml}$ per $\mathrm{mg}$ pancreas), and 6-wk$(1149 \pm 37.5 \mathrm{pg} / \mathrm{ml}$ per pancreas), 12-wk- (521 \pm 21.7 $\mathrm{pg} / \mathrm{ml}$ per mg pancreas), and 30-wk- $(180 \pm 21.3 \mathrm{pg} / \mathrm{ml}$ per $\mathrm{mg}$ pancreas) old $\mathrm{db} / \mathrm{db}$ mice were measured by ELISA.

\section{Plasma creatinine levels and histology of the kidneys of $\mathrm{db} / \mathrm{db}$ mice}

As shown in Fig. 10, plasma creatinine levels were significantly higher in 12-wk-old when compared to 6-wk-old $\mathrm{db} / \mathrm{db}$ mice $(3.41 \pm 0.20$ vs $1.47 \pm 0.46$ $\mathrm{mg} / \mathrm{dl}, \mathrm{p}<0.05)$, and in 30-wk-old compared to 12 -wk-old db/db mice $(4.65 \pm 0.03$ vs $3.41 \pm 0.20 \mathrm{mg} / \mathrm{dl}$, $\mathrm{p}<0.05)$. Electron microscopic images of the kidneys are shown in Fig. 1P-S. 12-wk and 30-wk db/db mice exhibited severe podocyte foot fusion. Electron dense deposits and increased numbers of mesangium cells were observed in the 30 -wk-old $\mathrm{db} / \mathrm{db}$ mice (Fig. $1 \mathrm{R}$ and S). 
A
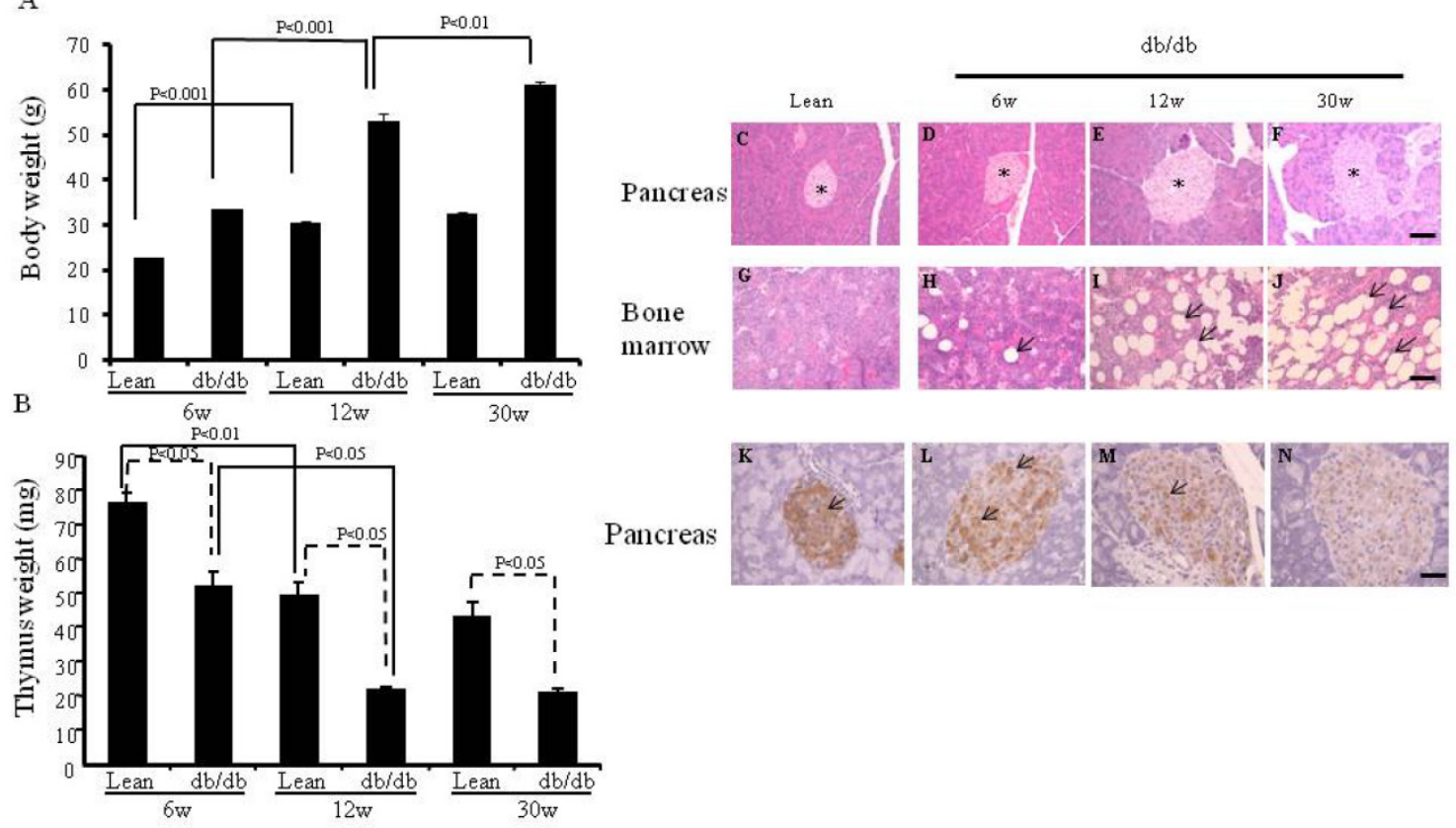

o

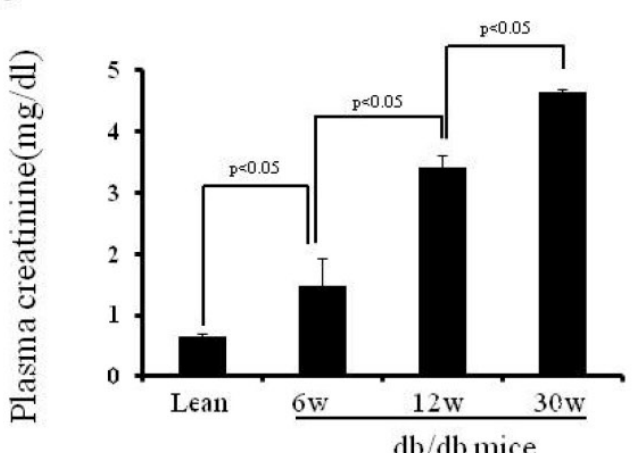

$\mathrm{db} / \mathrm{db}$ mice

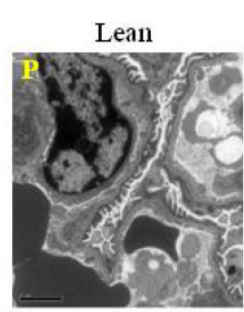

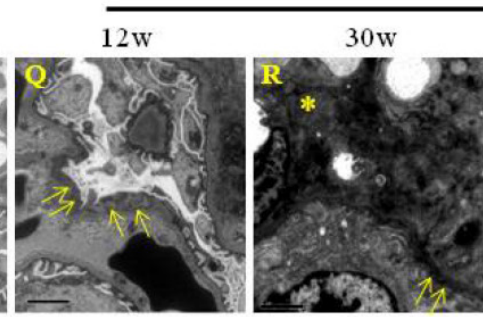

$\mathrm{x} 12000$

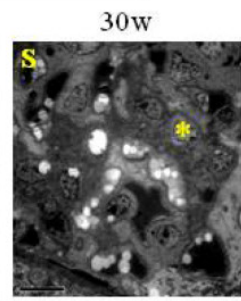

$\mathrm{x} 2500$

Figure I. Body weight, thymus weight and the morphology of pancreas and bone marrow, and expression of insulin on the pancreata, and plasma creatinine levels and images of electron microcopy. (A) Body weights are shown $\left({ }^{*}<<0.0 \mathrm{I}\right)$. (B) Thymus weights are shown $\left({ }^{*}<0.05\right)$. (C-J) HE staining of pancreas and bone marrow of the lean and $\mathrm{db} / \mathrm{db}$ mice at each age. The islets are shown (* in Fig.C-F). The adipocytes are shown in db/db mice (arrows in Fig. $\mathrm{H}-\mathrm{J})$ ). (K-N) Immunochemistry staining for insulin (arrows) was performed. Scale bar $=50 \mu \mathrm{m}$ in Fig. C-J, Scale bar $=25 \mu \mathrm{m}$ in Fig. K-N. (O) Plasma creatinine levels of lean, $(P<0.05)$. (P-S) EM of kidneys. Podocyte foot fusion is shown in Fig. $3 \mathrm{Q}$ and $\mathrm{R}$ (arrows). Electron dense deposits and increased mesangium cells $\left(^{*}\right)$ are shown in Fig. IR and S. Scale bar $=2 \mu \mathrm{m}$ in Fig. P-R, Scale bar $=10 \mu \mathrm{m}$ in Fig. S. The results are mean $\pm S E, n=6$ in each group. 


\section{Improved body weight, blood glucose and plasma adiponectin, and insulin levels 6 weeks after treatment with IBM-BMT +TT}

As seen in Fig.2A, body weight was significantly $(p<0.01)$ lower in the IBM-BMT+TT treated $\mathrm{db} / \mathrm{db}$ mice than in the age-matched non-treated $\mathrm{db} / \mathrm{db}$ mice. In addition, fasting blood glucose levels (Fig. 2B) were significantly $(p<0.01)$ lower in the treated $\mathrm{db} / \mathrm{db}$ mice than in the non-treated $\mathrm{db} / \mathrm{db}$ mice. Indeed IBM-BMT+TT reduced blood glucose to the levels found in age-matched lean mice. As shown in Fig. $2 \mathrm{C}$, the non-treated $\mathrm{db} / \mathrm{db}$ mice exhibited a significantly $(\mathrm{p}<0.05)$ lower level of plasma adiponectin than age-matched lean mice. However, the plasma adiponectin levels were significantly $(\mathrm{p}<0.05)$ increased in the treated $d b / d b$ mice when compared to the non-treated $\mathrm{db} / \mathrm{db}$ mice (Fig. $2 \mathrm{C}$ ). Plasma insulin levels were higher $(p<0.05)$ in the non-treated $d b / d b$ mice than in the age matched lean mice.
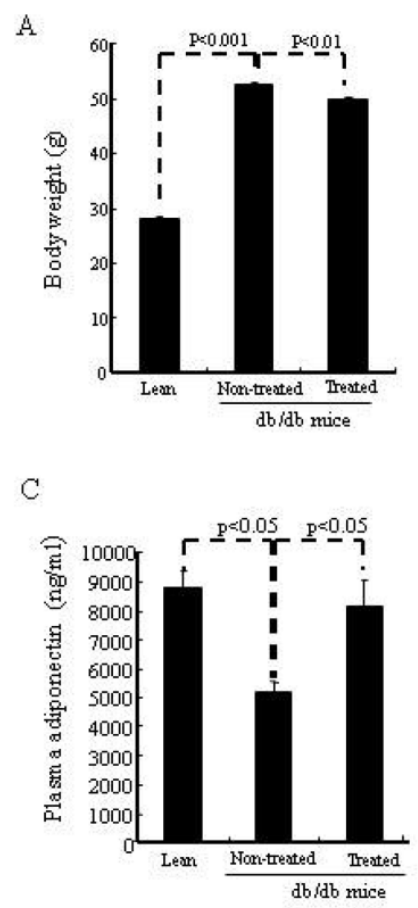

IBM-BMT+TT treatment resulted in a decrease $(p<0.05)$ in plasma insulin levels to the levels found in age-matched lean animals (Fig. 2D).

\section{Lymphocyte subpopulations in peripheral blood and cell number of thymus 6 weeks after treatment with IBM-BMT +TT}

The relative percentage of the total cell number in the thymus was significantly $(p<0.05)$ lower in the non-treated $\mathrm{db} / \mathrm{db}$ mice than in the lean mice $(65.13 \%$ of that of lean mice). The total cell number of the thymus was significantly higher $(\mathrm{p}<0.05)$ increased in the treated mice $(97.9 \%$ of lean mice) (Fig. 3A). Figure $3 \mathrm{~B}$ shows the percentages of donor-derived cells $\left(\mathrm{H}-2 \mathrm{~K}^{\mathrm{b}}\right)$ in the peripheral blood of the treated $\mathrm{db} / \mathrm{db}$ mice. The percentages of donor-derived $\mathrm{CD}^{+}$and $\mathrm{CD}^{+}$were $10.16 \%$ and $7.81 \%$ respectively, Figure 3C and $\mathrm{D}$.
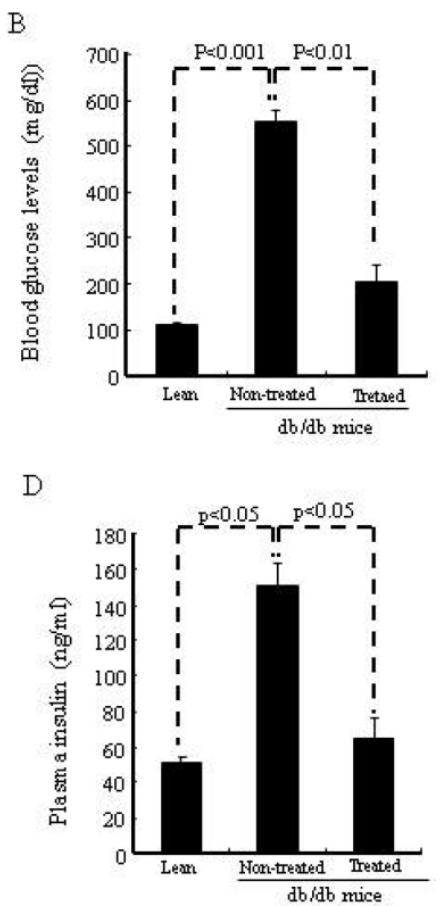

Figure 2. Body weight, blood glucose levels, plasma adiponectin, insulin. (A) Body weights are shown. (B) Blood glucose levels are shown. (C) Plasma adiponectin. (D) Plasma insulin. 

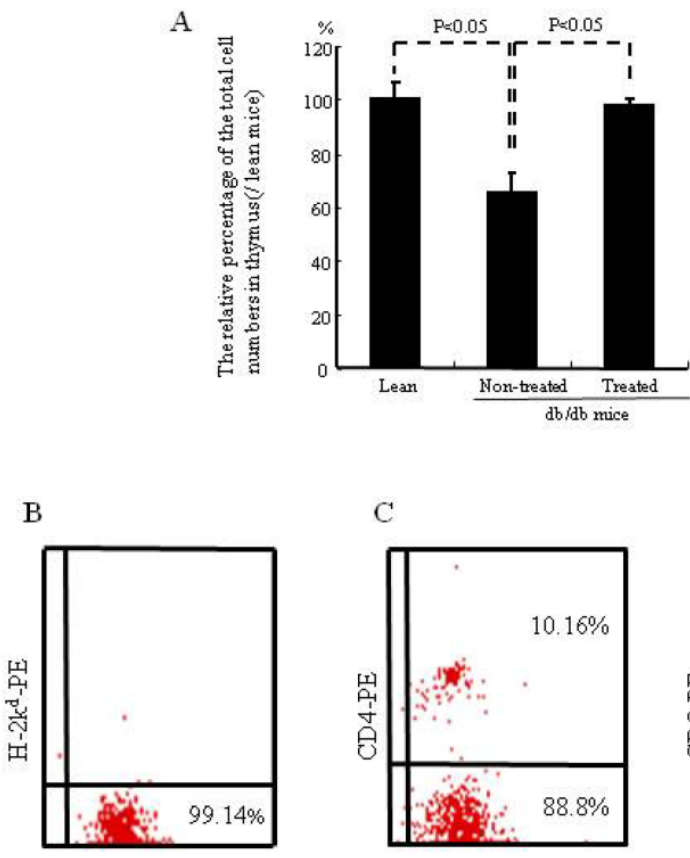

$\mathrm{D}$

$\mathrm{H}-2 \mathrm{k}^{\mathrm{b}}-\mathrm{FITC}$

Figure 3. Cell number of thymus and lymphocyte subpopulations in peripheral blood. (A) The relative percentage of total cell numbers in the thymus, which was significantly increased in the $\mathrm{db} / \mathrm{db}$ mice treated with IBM-BMT+TT. (B-D) Donor-derived cells in peripheral blood, $C D 4^{+}$cells and $C D 8^{+}$cells are shown. The results are mean $\pm S E, n=6$ in each group.

\section{Lymphocyte function}

Approximately $98 \%$ of hematolymphoid cells were of donor-origin in the peripheral blood of the recipients one month after IBM-BMT+TT treatment. Spleen cells of the recipient animals demonstrated mitogen responses to lipopolysaccharide, in contrast to those of non-treated $\mathrm{db} / \mathrm{db}$ mice: $26296 \pm 2780.93 \mathrm{vs}$ $19292 \pm 1310.42$, respectively, $p<0.05$. In lean mice the mitogen response was $31406 \pm 2780.93$. These findings suggest that IBM-BMT+TT treatment restores lymphocyte function in the $\mathrm{db} / \mathrm{db}$ mice.

\section{Expression of HO-I, iNOS, peNOS and PAKT in the kidney of $\mathrm{db} / \mathrm{db}$ mice treated with IBM-BMT+TT}

The expression of renal HO-1 was significantly lower $(\mathrm{p}<0.05)$ in the non-treated $\mathrm{db} / \mathrm{db}$ mice when compared to lean mice, but significantly increased $(\mathrm{p}<0.05)$ in $\mathrm{db} / \mathrm{db}$ mice treated with IBM-BMT+TT, when compared with non-treated $\mathrm{db} / \mathrm{db}$ mice (Fig.
$4 \mathrm{~A}$ and $\mathrm{B})$. The expression of iNOS was the receptacle of HO-1 expression and was significantly $(p<0.05)$ higher in the non-treated $\mathrm{db} / \mathrm{db}$ mice than in the lean mice. Densitometry analyses revealed a significant decrease in iNOS $(p<0.05)$ in the kidney of treated $\mathrm{db} / \mathrm{db}$ mice when compared with non-treated $\mathrm{db} / \mathrm{db}$ mice (Fig. 4A and C).

The expression of pAKT and peNOS in the kidney was significantly lower $(p<0.05)$ in the non-treated $\mathrm{db} / \mathrm{db}$ mice when compared to the lean mice, but there was a significant increase in the expression of both pAKT and peNOS in the IBM-BMT+TT treated $\mathrm{db} / \mathrm{db}$ mice, when compared with non-treated $\mathrm{db} / \mathrm{db}$ mice (Fig. 4D-G, $\mathrm{p}<0.05$ ). The expression of type IV collagen (brown color) was greater in the kidney of the non-treated $\mathrm{db} / \mathrm{db}$ mice (Fig. 4I) than in the lean mice (Fig. 4H). However, it was significantly lower in the kidney (arrows in Fig. $4 \mathrm{~J})$ in the treated $\mathrm{db} / \mathrm{db}$ mice than in the non-treated $\mathrm{db} / \mathrm{db}$ mice. 

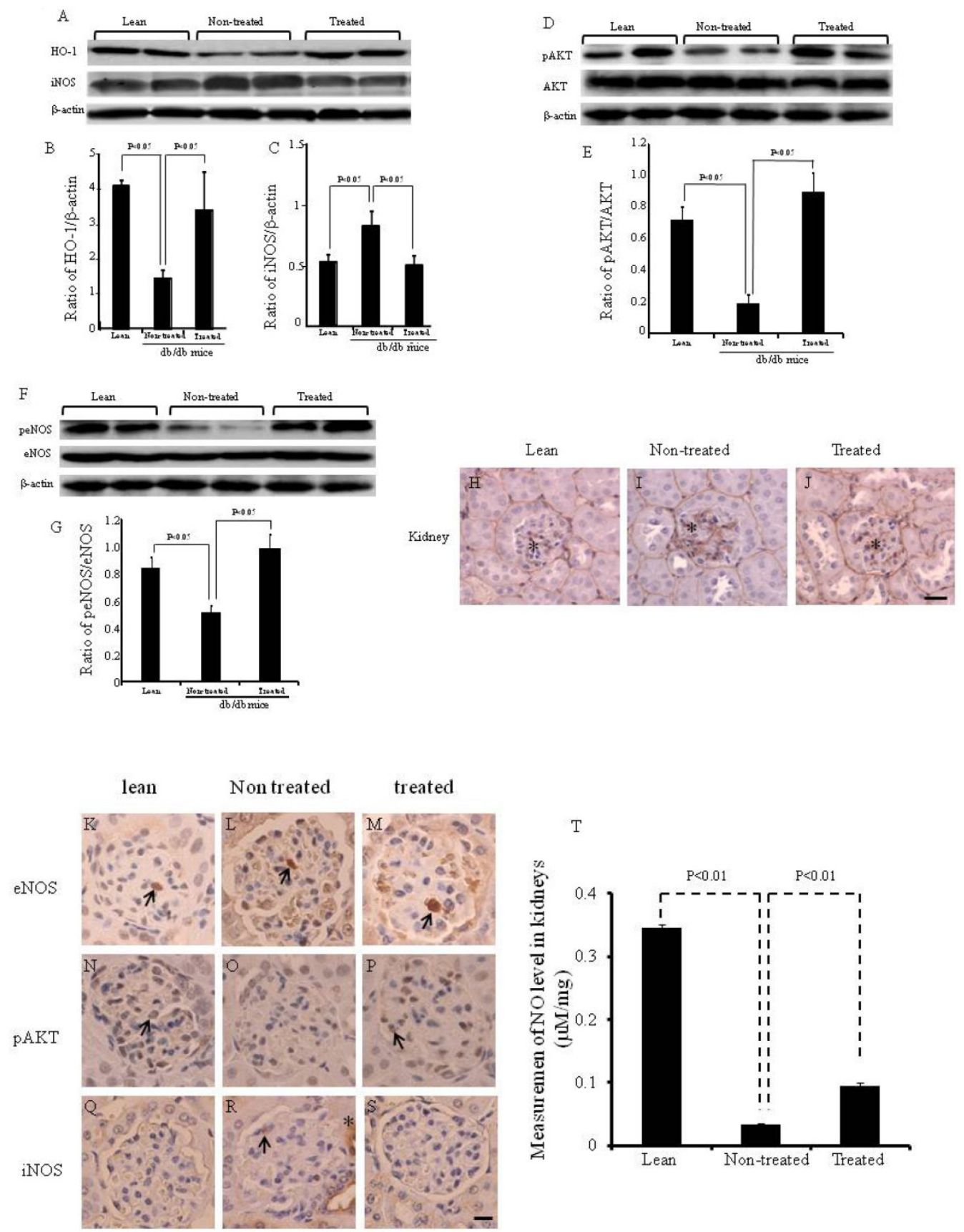

Figure 4. Expression of HO-I, iNOS AKT, pAKT, eNOS and peNOS in the kidney, and expression of type IV collagen in the kidneys. (A-C) Western blot and densitometry analysis of HO-I, iNOS and actin proteins in kidneys of lean, non-treated db/db mice and treated $\mathrm{db} / \mathrm{db}$ mice. ( $\mathrm{D}$ and $\mathrm{E}$ ) Western blot and densitometry analyses of AKT and pAKT and actin proteins in kidney of lean, non-treated $\mathrm{db} / \mathrm{db}$ mice and treated $\mathrm{db} / \mathrm{db}$ mice are shown. ( $F$ and $\mathrm{G}$ ) Western blot and densitometry analyses of eNOS and peNOS and actin proteins in kidney of lean, non-treated db/db mice and treated db/db mice are shown. Representative immunoblots are shown. There were significant differences between non-treated and treated groups $(p<0.05)$. $(\mathrm{H}-\mathrm{J})$ Immunochemistry staining for type IV collagen $(*)$. (K-S) Immunochemistry staining for eNOS, PAKT and iNOS. Scale bar $=25 \mu \mathrm{m}$. (T) NO levels in the kidney.

The expression of peNOS, pAKT and iNOS was confirmed by immunochemistry staining (Fig. 4K-T). eNOS positive cells were identified in the kidneys of lean, non-treated and treated $\mathrm{db} / \mathrm{db}$ mice ( arrow in Fig. 4K-M). pAKT positive cells were identified in the kidney of lean and treated $\mathrm{db} / \mathrm{db}$ mice (arrow in Fig. $4 \mathrm{~N}$ and $\mathrm{P}$ ). However, none were found in the non-treated $\mathrm{db} / \mathrm{db}$ mice. iNOS positive cells were identified in the kidney of non-treated $\mathrm{db} / \mathrm{db}$ mice (arrow and *in Fig. 4R). 
As shown in Fig. 4T, NO levels in the kidney were significantly lower in non-treated $\mathrm{db} / \mathrm{db}$ mice when compared to lean mice $(0.35 \pm 0.004$ vs $0.03 \pm 0.002$ $\mu \mathrm{M} / \mathrm{mg}, \mathrm{p}<0.01)$. However, the NO levels were significantly higher in the kidney $(0.09 \pm 0.005$ vs $0.03 \pm 0.002 \mu \mathrm{M} / \mathrm{mg}, \mathrm{p}<0.01)$ in the treated $\mathrm{db} / \mathrm{db}$ mice than in the non-treated $\mathrm{db} / \mathrm{db}$ mice.

\section{Discussion}

Leptin receptor-deficient $\mathrm{db} / \mathrm{db}$ mice exhibit severe hereditary obesity [17] and display hormonal imbalances and hematolymphoid defects [18, 19]. $\mathrm{db} / \mathrm{db}$ mice exhibit a marked reduction in the size and cellularity of the thymus [20,21]. Thus we firstly confirmed the body weight and thymus weight of $\mathrm{db} / \mathrm{db}$ and lean mice at each age that were maintained in our animal facilities. Meantime, the morphology of the pancreas, kidney and bone marrow was also confirmed (Figure 1-3). There were significant differences in body weight and thymus weight between 6-wk-and 12-wk-old mice. The pancreas, kidney and bone marrow showed differences in morphology at each time point. Previous studies have shown that IBM-BMT+TT improved insulin sensitivity in $\mathrm{db} / \mathrm{db}$ mice $7 \mathrm{wks}$ after treatment [7]. However, there are no reports indicating whether IBM-BMT+TT increased HO-1 expression, or benefited the kidney in $\mathrm{db} / \mathrm{db}$ mice, although a protective effect of BMT on renal pathology has been reported [22].

$\mathrm{HO}-1$ is the inducible form of $\mathrm{HO}(\mathrm{HO}-2$ is the constitute form) and is increased in response to OS. Increased levels of HO-1 slow the rate of weight gain and decrease levels of TNF-a and IL-6, but increase serum levels of adiponectin in obese diabetic mice [15]. $\mathrm{db} / \mathrm{db}$ mice treated with IBM-BMT+TT exhibited a larger decrease in body weight and plasma insulin levels than age-matched non-treated $\mathrm{db} / \mathrm{db}$ mice. Insulin administration to treated $\mathrm{db} / \mathrm{db}$ mice produced a rapid decrease in blood glucose levels, suggesting improved insulin sensitivity after IBM-BMT+TT treatment. In the present study, HO-1 expression increased in the kidney after IBM-BMT+TT and was accompanied by an enhanced expression of peNOS and pAKT. A reduction in the production of nitric oxide [23] and a decrease in the expression of eNOS are reportedly associated with advanced DN [24]. An increase in AKT signaling is considered an important metabolic response to OS through the attenuation of ROS-mediated endothelial dysfunction [25]. The up regulation of renal HO-1 expression with a resultant increase in signaling molecules, including adiponectin via the pAKT-pAMPK-peNOS pathway, prevents the development of metabolic syndrome and improves both vascular and renal function [26].
HO has been shown to be important for attenuating the overall production of reactive oxygen species (ROS) through its ability to degrade heme and to produce carbon monoxide (CO), biliverdin/bilirubin, and the release of free iron, which possess potent antioxidant properties and antiapoptotic effects [26]. Recently, the induction of HO-1 has been found to reduce diabetic induced-glomerular injury and apoptosis, and these effects are associated with decreased NF-kB-induced inflammation and oxidative stress [27]. MSCs have the capacity to repair renal injury, accelerate tubular proliferation and improve renal function, and upregulate HO-1 expression and increase HO activity, all are essential for MSC growth and differentiation to the osteoblast lineage, which is consistent with the role of HO-1 in hematopoietic stem cell differentiation [28]. Induction of HO-1 by cobalt-protoporphyrin IX in recipient mice before conditioning and bone marrow transplantation (BMT) results in a reduction of GVHD and improved survival [29]. One report has indicated that HO-1 in dendritic cells may function as an inhibitor of the alloimmune response mediated by $\mathrm{CD} 4+\mathrm{T}$ cells. HO-1 could thus play a key role in the design of therapies to prolong allograft function, based on the potent alloimmunity modulating capacity of this enzyme [30].

Plasma adiponectin levels are also significantly higher in treated $\mathrm{db} / \mathrm{db}$ mice than in non-treated $\mathrm{db} / \mathrm{db}$ mice. Adiponectin is a key regulator of albuminuria, suppressing not only i) OS and albuminuria but also ii) high levels of adiponectin phosphorylase and iii) active AMPK, presumably via adipoR1, which prevents OS and the fusion of the podocyte foot processes [31]. There is a report supporting the hypothesis that adiponectin is critical for both endothelial cell survival and function via the activation of eNOS and crosstalk between pAKT and pAMPK [32].

Bone marrow cells have the capacity to differentiate into mesangial cells $[33,34]$ and to transdifferentiate into podocytes. This is accompanied by the re-expression of the defective collagen chains and improved renal histology and function [35]. MSCs have the capacity to repair renal injury, accelerate tubular proliferation and improve renal function [36, 37]. Nephrons are of mesenchymal origin and stroma cells are of crucial importance for signaling, leading to the differentiation of both nephrons and collecting ducts [38]. Bone marrow-derived mesangial cell progenitors may play a crucial role in the development and progression of extracellular matrix accumulation and mesangial cell proliferation in the $\mathrm{db} / \mathrm{db}$ mouse. Future studies to clarify extra-cellular matrix accumulation will focus on the donor-derived BM cells in the kidneys of the recipient. 
Type IV collagen is a major structural component of all basement membranes, including the glomerular basement membrane of the kidney in vertebrates and invertebrates [39, 40]. Our results show that the expression of type IV collagen in the glomerulus was attenuated after IBM-BMT+TT. BM-derived cells fuse with existing glomerular cells and thereby provide therapeutic benefit or, alternatively, transfer their nuclei to damaged podocytes and thereby enable repair. Bone marrow-derived stem cells repair basement membrane collagen defects and reverse genetic kidney disease [35].

Age-related hematologic changes are associated with a decline in BM cellularity and a decline in adaptive immunity [41, 42]. The thymus involutes steadily with increasing age, resulting in a decreased release of new naïve $\mathrm{T}$ cells to the periphery, thereby affecting adaptive immunity [43]. The thymus also undergoes age-related progressive involution with decreased thymic lymphopoiesis, reduced thymic size and disrupted thymic architecture. Our previous studies demonstrated that the thymus is significantly lighter in $\mathrm{db} / \mathrm{db}$ mice than in age-matched lean mice. When thymi from newborn C57BL6 mice were transplanted into $\mathrm{db} / \mathrm{db}$ mice, the percentage of double-positive, double-negative and CD4+ cells in the thymus was normalized, as was the CD4/CD8 ratio in the peripheral blood [7], and the total cell number of the thymus, suggesting that IBM-BMT+TT is capable of restoring the immune repertoire and overcoming the autoimmune response, which is considered to be partly responsible for the development of diabetes.

IBM-BMT appears to be the most appropriate strategy for allogenic BMT [4]. Moreover, allogenic IBM-BMT+TT normalizes $\mathrm{T}$ cell subsets, cytokine imbalance and insulin sensitivity in $\mathrm{db} / \mathrm{db}$ mice [7]. Allogenic IBM-BMT+TT upregulates the expression of HO-1 in kidney. This is followed by the upregulation of peNOS and pAKT and a reduction in iNOS levels, resulting in an improvement in renal function. This therapeutic approach offers decided advantages in the treatment of both autoimmune and hematological diseases.

\section{Supplementary Material}

Supplementary Figure 1.

http://www.ijbs.com/v08p1335s1.pdf

\section{Abbreviations}

DN: diabetic nephropathy; GVHD: Graft versus host disease; HO: Heme oxygenase; IBM-BMT: Intra bone marrow-bone marrow transplantation; iNOS: inducible nitric oxide synthase; NO: Nitric oxide; OS: Oxidative stress; pAKT: phosphorylated AK trans- forming; peNOS: phosphorylated endothelial nitric oxide synthase; pLKB1: phosphorylated liver kinase B1; pAMPK: phosphorylated adenosine monophosphate-activated protein kinase; TT: thymus transplantation.

\section{Acknowledgments}

We would like to thank Mr. Hilary Eastwick-Field and Ms. Keiko Ando for their help in the preparation of the manuscript. This study was supported by Otsuka Pharmaceutical Company, Ltd and by NIH grants DK068234, HL55601, HL34300 (NGA). We thank Ms Aiko Kitajima for her excellent technical assistance regarding the morphology studies.

\section{Competing Interests}

The authors have declared that no competing interest exists.

\section{References}

1. Otterbein LE, Soares MP, Yamashita K, Bach FH. Heme oxygenase-1: unleashing the protective properties of heme. Trends Immunol. 2003; 24: 449-55.

2. Orozco LD, Kapturczak MH, Barajas B, Wang X, Weinstein MM, Wong J, et al. Heme oxygenase-1 expression in macrophages plays a beneficial role in atherosclerosis. Circ Res. 2007; 100: 1703-11.

3. Goulmy E, Schipper R, Pool J, Blokland E, Falkenburg JH, Vossen J, et al. Mismatches of minor histocompatibility antigens between HLA-identical donors and recipients and the development of graft-versus-host disease after bone marrow transplantation. N Engl J Med. 1996; 334: 281-5.

4. Ikehara S. A novel strategy for allogeneic stem cell transplantation: perfusion method plus intra-bone marrow injection of stem cells. Exp Hematol. 2003; 31: 1142-6.

5. Nakamura K, Inaba M, Sugiura K, Yoshimura T, Kwon AH, Kamiyama $Y$, et al. Enhancement of allogeneic hematopoietic stem cell engraftment and prevention of GVHD by intra-bone marrow bone marrow transplantation plus donor lymphocyte infusion. Stem Cells. 2004; 22: 125-34.

6. Hosaka N, Nose M, Kyogoku M, Nagata N, Miyashima S, Good RA, et al. Thymus transplantation, a critical factor for correction of autoimmune disease in aging MRL/+mice. Proc Natl Acad Sci U S A. 1996; 93 : 8558-62.

7. Li M, Abraham NG, Vanella L, Zhang Y, Inaba M, Hosaka N, et al. Successful modulation of type 2 diabetes in $\mathrm{db} / \mathrm{db}$ mice with intra-bone marrow--bone marrow transplantation plus concurrent thymic transplantation. J Autoimmun. 2010; 35: 414-23.

8. Breyer MD, Bottinger E, Brosius FC, 3rd, Coffman TM, Harris RC, Heilig $\mathrm{CW}$, et al. Mouse models of diabetic nephropathy. J Am Soc Nephrol. 2005; 16: 27-45.

9. Ziyadeh FN, Hoffman BB, Han DC, Iglesias-De La Cruz MC, Hong SW, Isono $\mathrm{M}$, et al. Long-term prevention of renal insufficiency, excess matrix gene expression, and glomerular mesangial matrix expansion by treatment with monoclonal antitransforming growth factor-beta antibody in db/db diabetic mice. Proc Natl Acad Sci U S A. 2000; 97: 8015-20.

10. Ritz E, Tarng DC. Renal disease in type 2 diabetes. Nephrol Dial Transplant. 2001; 16 Suppl 5: 11-8.

11. Baynes JW. Role of oxidative stress in development of complications in diabetes. Diabetes. 1991; 40: 405-12.

12. Kakimoto $M$, Inoguchi $T$, Sonta $T$, Yu HY, Imamura $M$, Etoh $T$, et al. Accumulation of 8-hydroxy-2'-deoxyguanosine and mitochondrial DNA deletion in kidney of diabetic rats. Diabetes. 2002; 51: 1588-95.

13. Abraham NG, Li M, Vanella L, Peterson SJ, Ikehara S, Asprinio D. Bone marrow stem cell transplant into intra-bone cavity prevents type 2 diabetes: role of heme oxygenase-adiponectin. J Autoimmun. 2008; 30: 128-35. 
14. Toki J, Adachi Y, Jin T, Fan T, Takase K, Lian Z, et al. Enhancement of IL-7 following irradiation of fetal thymus. Immunobiology. 2003; 207: 247-58.

15. Li M, Kim DH, Tsenovoy PL, Peterson SJ, Rezzani R, Rodella LF, et al. Treatment of obese diabetic mice with a heme oxygenase inducer reduces visceral and subcutaneous adiposity, increases adiponectin levels, and improves insulin sensitivity and glucose tolerance. Diabetes. 2008; 57: 1526-35.

16. Peterson SJ, Kim DH, Li M, Positano V, Vanella L, Rodella LF, et al. The L-4F mimetic peptide prevents insulin resistance through increased levels of HO-1, pAMPK, and pAKT in obese mice. J Lipid Res. 2009; 50: 1293-304.

17. Chua SC, Jr., Chung WK, Wu-Peng XS, Zhang Y, Liu SM, Tartaglia L, et al. Phenotypes of mouse diabetes and rat fatty due to mutations in the OB (leptin) receptor. Science. 1996; 271: 994-6.

18. Fantuzzi G, Faggioni R. Leptin in the regulation of immunity, inflammation, and hematopoiesis. J Leukoc Biol. 2000; 68: 437-46.

19. Matarese G, Moschos S, Mantzoros CS. Leptin in immunology. J Immunol. 2005; 174: 3137-42.

20. Fernandes G, Handwerger BS, Yunis EJ, Brown DM. Immune response in the mutant diabetic C57BL/Ks-dt+ mouse. Discrepancies between in vitro and in vivo immunological assays. J Clin Invest. 1978; 61: 243-50.

21. Kimura M, Tanaka S, Isoda F, Sekigawa K, Yamakawa T, Sekihara H. T lymphopenia in obese diabetic $(\mathrm{db} / \mathrm{db})$ mice is non-selective and thymus independent. Life Sci. 1998; 62: 1243-50.

22. Flaquer M, Franquesa M, Barquinero J, Lloberas N, Gutierrez C, Torras J, et al. Bone marrow transplantation induces normoglycemia in a type 2 diabetes mellitus murine model. Transplant Proc. 2009; 41: 2282-5.

23. Amiri F, Shaw S, Wang X, Tang J, Waller JL, Eaton DC, et al. Angiotensin II activation of the JAK/STAT pathway in mesangial cells is altered by high glucose. Kidney Int. 2002; 61: 1605-16.

24. Marrero MB, Banes-Berceli AK, Stern DM, Eaton DC. Role of the JAK/STAT signaling pathway in diabetic nephropathy. Am J Physiol Renal Physiol. 2006; 290: F762-8.

25. Schulz E, Dopheide J, Schuhmacher S, Thomas SR, Chen K, Daiber A, et al. Suppression of the JNK pathway by induction of a metabolic stress response prevents vascular injury and dysfunction. Circulation. 2008; 118: 1347-57.

26. Abraham NG, Cao J, Sacerdoti D, Li X, Drummond G. Heme oxygenase: the key to renal function regulation. Am J Physiol Renal Physiol. 2009; 297: F1137-52.

27. Elmarakby AA, Faulkner J, Baban B, Saleh MA, Sullivan JC. Induction of hemeoxygenase-1 reduces glomerular injury and apoptosis in diabetic spontaneously hypertensive rats. Am J Physiol Renal Physiol. 2012; 302: F791-800.

28. Vanella L, Sanford C, Jr., Kim DH, Abraham NG, Ebraheim N. Oxidative stress and heme oxygenase- 1 regulated human mesenchymal stem cells differentiation. Int J Hypertens. 2012; 2012: 890671.

29. Gerbitz A, Ewing P, Wilke A, Schubert T, Eissner G, Dietl B, et al. Induction of heme oxygenase-1 before conditioning results in improved survival and reduced graft-versus-host disease after experimental allogeneic bone marrow transplantation. Biol Blood Marrow Transplant. 2004; 10: 461-72.

30. Cheng C, Noorderloos M, van Deel ED, Tempel D, den Dekker W, Wagtmans $\mathrm{K}$, et al. Dendritic cell function in transplantation arteriosclerosis is regulated by heme oxygenase 1 . Circ Res. 2010; 106: 1656-66.

31. Sharma K, Ramachandrarao S, Qiu G, Usui HK, Zhu Y, Dunn SR, et al. Adiponectin regulates albuminuria and podocyte function in mice. J Clin Invest. 2008; 118: 1645-56.

32. Ouchi N, Kobayashi H, Kihara S, Kumada M, Sato K, Inoue T, et al. Adiponectin stimulates angiogenesis by promoting cross-talk between AMP-activated protein kinase and Akt signaling in endothelial cells. J Biol Chem. 2004; 279: 1304-9.

33. Ito T, Suzuki A, Imai E, Okabe M, Hori M. Bone marrow is a reservoir of repopulating mesangial cells during glomerular remodeling. J Am Soc Nephrol. 2001; 12: 2625-35.

34. Wong CY, Cheong SK, Mok PL, Leong CF. Differentiation of human mesenchymal stem cells into mesangial cells in post-glomerular injury murine model. Pathology. 2008; 40: 52-7.

35. Sugimoto $H$, Mundel TM, Sund M, Xie L, Cosgrove D, Kalluri R. Bone-marrow-derived stem cells repair basement membrane collagen defects and reverse genetic kidney disease. Proc Natl Acad Sci U S A. 2006; 103: 7321-6.

36. Lange C, Togel F, Ittrich H, Clayton F, Nolte-Ernsting C, Zander AR, et al. Administered mesenchymal stem cells enhance recovery from ischemia/reperfusion-induced acute renal failure in rats. Kidney Int. 2005; 68: 1613-7.

37. Morigi M, Imberti B, Zoja C, Corna D, Tomasoni S, Abbate M, et al. Mesenchymal stem cells are renotropic, helping to repair the kidney and improve function in acute renal failure. J Am Soc Nephrol. 2004; 15: 1794-804.

38. Anglani F, Forino M, Del Prete D, Tosetto E, Torregrossa R, D'Angelo A. In search of adult renal stem cells. J Cell Mol Med. 2004; 8: 474-87.

39. Kalluri R, Shield CF, Todd P, Hudson BG, Neilson EG. Isoform switching of type IV collagen is developmentally arrested in X-linked Alport syndrome leading to increased susceptibility of renal basement membranes to endoproteolysis. J Clin Invest. 1997; 99: 2470-8.

40. Hudson BG, Tryggvason K, Sundaramoorthy M, Neilson EG. Alport's syndrome, Goodpasture's syndrome, and type IV collagen. N Engl J Med. 2003; 348: 2543-56.

41. Hakim FT, Gress RE. Immunosenescence: deficits in adaptive immunity in the elderly. Tissue Antigens. 2007; 70: 179-89.

42. Linton PJ, Dorshkind K. Age-related changes in lymphocyte development and function. Nat Immunol. 2004; 5: 133-9.

43. Aspinall R. Age-associated thymic atrophy in the mouse is due to a deficiency affecting rearrangement of the TCR during intrathymic T cell development. J Immunol. 1997; 158: 3037-45. 